\title{
Is Effective and Structured Training key to Successful Biomedical Waste Management in Hospital : A Study
}

\author{
SHISHIR BASARKAR \\ Seven Hills Hospitals, Mumbai - 400 059, Maharashtra, India. \\ http://dx.doi.org/10.12944/CWE.9.1.18
}

(Received: January 29, 2014; Accepted: February 24, 2014)

\begin{abstract}
The study is interventional in nature because the training has been done as an intervention. The study was done to find out the impact of training on knowledge level of the hospital staff who is dealing with biomedical waste on day to day basis. The study was conducted on 184 staff members during July-Sept 2012 in multispecialty tertiary care hospital. The survey form was prepared and was applied to all participants in person before and after the training was conducted. The training programme on biomedical waste management was for total 60 hours of which 40 hours were class room lectures and 20 hours practice sessions. the Methods used in the analysis of data were chi-square and t-tests. Of total study participants $71.7 \%(132)$ were female while $28.2 \%(52)$ were male. nursing staff constituted $54.3 \%$ (100), medical staff $20.1 \%$ (37), house keeping $17.3 \%$ (32) while general management $8.1 \%$ (15). a significant statistical difference (pretraining and post training) was found among these staff members who have received training in biomedical waste management which is evident from the raised level of knowledge and awareness about biomedical waste management. The safe management of biomedical waste is of paramount importance for the hospital staff, patients as well as community population. Hospital staff is responsible for safe disposal of waste and that can be reinforce with the help of structured training programme.
\end{abstract}

Key words :Hospital, Biomedical waste, Training, Medical, Nursing.

\section{INTRODUCTION}

The biomedical waste which is generated from various types of healthcare facilities and if not managed properly then give rise to considerable environmental pollution. The untreated waste poses significant health risk to patients, visitors, care givers and community as a whole. the waste generated in hospital has been categories in various subtypes like 1 . Of the total waste $85 \%$ is non infectious while $10 \%$ is infectious and $5 \%$ hazardous ${ }^{2}$.

Development of infections of various types from these medical waste is common occurrence of which most dangerous are HIV, Hepatitis C, Hepatitis B. These viral borne infections are mostly caused by contaminated waste which contain piercing items like needles, blades, glass etc. ${ }^{3}$
If this waste is categorized as infectious waste per se then it will increase the quantum of waste leading to increase in both financial as well as labour cost. hence it is imperative to segregate the waste at the site of generation or at the location of their use ${ }^{4}$. When such waste is not properly treated and managed then it create various public health issues that is the reason the waste as generated must be segregated as per the class it belongs to ${ }^{4}$.

It is not the segregation which is important the process of collection, transportation , treatment and final disposal of biomedical waste are mandatory as per the biomedical waste (management and handling) rules 1998 which are amended in 2000 and $2003^{5}$. 
The management of the biomedical waste is an ongoing process and cannot be completed by mere instruction rather need training of the stake holder. Training of the staff is the hospital occupier's responsibility. Head of the institution should ensure that there is structured training schedule is laid down and conducted as per the scheduled. Training to the stake holders can be imparted either by internal trainers or external trainers. Hospital can also have a programme of train the trainers as well ${ }^{5}$

Training on biomedical waste management process can be given by designated biomedical waste management officer or infection control officer ${ }^{5}$

In order to prevent waste related injuries to staff, patients, visitors and environment there is need of acquiring knowledge, attitude and behavior by all the concerned staff members ${ }^{6}$. More over it is mandatory for hospital to have effective biomedical waste management plan to have medical waste controlled and rendered harmless. This goal realization make all the stake holders to have sufficient knowledge on the subject of waste management and if not done then what are hazards to the population and legal implications. Desired success on effective waste management can be achieved through the process of in house training by designated trainer who have grasped the importance of the subject.
Present study was performed in order to investigate whether training has desired impact on knowledge and attitude level of hospital stake holders dealing with biomedical waste management.

\section{MATERIALS AND METHODS}

The study was conducted between July to Sept 2012. No sampling was used in our study as almost all the staff members who are concerned with biomedical waste management were included. Study was conducted with 184 participants composed of staff from various department like wards, operation theater, intensive care units, hemodialysis units, endoscopy, emergency unit and procedure room.

The training was planned and structured and was consist of following topics.

1. Defining and classification of Biomedical waste. process of segregation, collection , storage , transportation,treatment and final disposal.

2. Health hazards of biomedical waste and Biomedical waste (management and handling)Rules 1998.

3. practical applications of biomedical waste management

4. A total 60 hours of training was imparted in batches of 20. Training was divided in to two subsets class room lectures and practical

Table 1: Demographic Features of the Hospital Staff $(\mathrm{N}=184)$

\begin{tabular}{lccc}
\hline Demographic Features & $\begin{array}{c}\text { Number } \\
\text { of staff (n) }\end{array}$ & $\begin{array}{c}\text { Percentage } \\
(\mathbf{\%})\end{array}$ & $\begin{array}{c}\text { Cumulative } \\
\text { Percentage (\%) }\end{array}$ \\
\hline Female & 132 & 71.8 & 71.8 \\
Male & 52 & 28.2 & $100 \%$ \\
Medical staff & 100 & 54.4 & 54.4 \\
Nursing staff & 37 & 20.1 & 74.5 \\
Housekeeping staff & 32 & 17.4 & 91.9 \\
General management staff & 15 & 8.1 & $100 \%$ \\
Age below 25 years & 71 & 38.6 & 38.6 \\
Age between 25-30years & 82 & 44.5 & 83.1 \\
Age more than 30 years & 31 & 16.9 & $100 \%$ \\
Work experience less than 5 years & 72 & 39.2 & 39.2 \\
Work experience between 5 - 10 years & 89 & 48.3 & 87.5 \\
Work experience more than 10 years & 23 & 12.5 & $100 \%$ \\
\hline
\end{tabular}


applications. Of 60 hours of training 40 hours were lectures and 20 hours practical aspect of the biomedical waste management. Both training sessions class room as well as practical were interactive in nature based on androgogy pattern of training and all participants were encouraged to put in their verbal, written opinion or questions on the subject under discussion.

\section{Measurement of effectiveness of the training}

The main stay of the sturdy was questionnaire which was prepared and tested with small group of staff (eighteen staff members) to determine whether questions were understood in the correct manner by the study participants. questions were revised according to results obtained and then applied to entire group considered for study. survey was done before initiation of training and then after training and consisted of 25 questions of which some were on socio demographic characteristics and their level of information on various steps of biomedical waste management process in the hospital.

All participants took interest in training sessions and answering questions of survey. The data collected in the study were evaluated through SPSS 11.5 programme. chi - square method was used in statistical analysis and $\mathrm{p}<0.05$ was taken as statistically significant. other statistical variables like means and percentages were also used in the analysis process of the collected data.

\section{RESULTS}

Of 184 study participants $71.7 \%$ (132) were female and 28.2 (52) were male of whom $44.5 \%$ (82) werre in the age group of 25 to 30 years. $42.9 \%$ (79) has previous experience of working in hospital and dealing with biomedical waste. 54.3\% (100)were nurses, $20.1 \%$ (37) were medial staff mainly medical officer and clinical assistants, $17.3 \%$ (32) housekeeping staff and $8.1 \%$ (15) belonging to general management staff. Of the participants $39.2 \%$ has work experience for less than five years.

Statistical significant difference were found between points received by all hospital staff in the preliminary test and final test $(p<0.05)$. The study disclosed that the points received by participants were higher in post training test in comparison to pre training test. The number of correct answers were increased in post training

Table 2: Comparision of PreTraining and Post Training Test

Response on BioMedical Waste Management Subject

\begin{tabular}{|c|c|c|c|c|}
\hline \multirow[t]{2}{*}{ Variable } & \multirow{2}{*}{$\begin{array}{l}\text { Pretraining test } \\
\qquad \pm \pm s . s\end{array}$} & \multirow{2}{*}{$\begin{array}{l}\text { Post training } \\
\text { Test } X \pm \text { s.s }\end{array}$} & \multicolumn{2}{|c|}{ Statistical Significance } \\
\hline & & & $\mathbf{t}$ & $\mathbf{p}$ \\
\hline Female $(n=80)$ & $32.13 \pm 3.25$ & $37.35 \pm 6.20$ & -6.41 & 0.000 \\
\hline Male $(n=104)$ & $29.40 \pm 7.08$ & $32.45 \pm 6.27$ & -14.21 & 0.000 \\
\hline Medical staff $(n=37)$ & $31.50 \pm 3.40$ & $38.15 \pm 1.86$ & -8.54 & 0.000 \\
\hline Nursing staff $(\mathrm{n}=100)$ & $30.31 \pm 4.40$ & $38.07 \pm 2.80$ & -14.43 & 0.000 \\
\hline Housekeeping staff( $n=32)$ & $29.65 \pm 5.23$ & $34.21 \pm 7.42$ & -3.55 & 0.002 \\
\hline General management staff $(n=15)$ & $28.46 \pm 3.80$ & $35.90 \pm 3.72$ & -7.64 & 0.000 \\
\hline Age below 25 years $(n=71)$ & $30.08 \pm 5.23$ & $36.60 \pm 4.32$ & -9.40 & 0.000 \\
\hline Age between $25-30$ years $(n=82)$ & $32.29 \pm 3.62$ & $37.55 \pm 3.81$ & -12.45 & 0.000 \\
\hline Age more than 30 years $(n=31)$ & $30.19 \pm 4.95$ & $37.30 \pm 5.58$ & -7.82 & 0.000 \\
\hline $\begin{array}{l}\text { Work experience less than } \\
5 \text { years }(n=72)\end{array}$ & $33.01 \pm 4.32$ & $38.00 \pm 2.00$ & -10.42 & 0.000 \\
\hline $\begin{array}{l}\text { Work experience between } \\
5-10 \text { years }(n=89)\end{array}$ & $32.45 \pm 5.16$ & $36.70 \pm 5.64$ & -5.55 & 0.000 \\
\hline $\begin{array}{l}\text { Work experience more than } \\
10 \text { years }(n=23)\end{array}$ & $32.40 \pm 3.18$ & $38.15 \pm 4.60$ & -7.36 & 0.000 \\
\hline
\end{tabular}

$\mathrm{p}<0.05$ 
session and it is concluded that knowledge level of all participants of study has increased as a result of training.

A ratio of $55.7 \%$ (29) of male and $48.4 \%$ (64) of the female participants have informed that they had no previous training on biomedical waste management process. while $28.8 \%$ (15) of male and $40.1 \%$ (53) of female of the study participants claimed to have undergone at least one training annually on the subject of biomedical waste management. As per gender the ratio of the staff who underwent training programme conducted in house on biomedical waste management was also

Table 3: Analysis of the hospital staff's demographic features regarding training status on the subject of BioMedical Waste Management $(\mathrm{N}=184)$

\begin{tabular}{|c|c|c|c|c|c|c|c|}
\hline \multirow[t]{2}{*}{ Variables } & \multicolumn{2}{|c|}{$\begin{array}{l}\text { Never under } \\
\text { any training }\end{array}$} & \multicolumn{2}{|c|}{$\begin{array}{c}\text { Underwent } \\
\text { training once only } \\
\end{array}$} & \multicolumn{2}{|c|}{$\begin{array}{l}\text { Underwent training } \\
\text { more than once }\end{array}$} & \multirow[t]{2}{*}{$\begin{array}{l}\text { Statistical } \\
\text { Significance }\end{array}$} \\
\hline & $\mathbf{n}$ & $\%$ & $\mathbf{n}$ & $\%$ & $\mathbf{n}$ & $\%$ & \\
\hline Male $(n=52)$ & 29 & 55.7 & 15 & 28.8 & 8 & 15.3 & 0.01 \\
\hline Female $(n=132)$ & 64 & 48.4 & 53 & 40.1 & 19 & 14.3 & \\
\hline Medical staff $(n=37)$ & 18 & 48.6 & 15 & 40.5 & 4 & 10.8 & 0.01 \\
\hline Nursing staff $(n=100)$ & 63 & 63.0 & 28 & 28.0 & 9 & 9.0 & \\
\hline $\begin{array}{l}\text { Housekeeping staff } \\
(\mathrm{n}=32)\end{array}$ & 18 & 56.2 & 8 & 25.0 & 6 & 18.7 & \\
\hline $\begin{array}{l}\text { General management } \\
\text { staff }(n=15)\end{array}$ & 11 & 73.3 & 2 & 13.3 & 2 & 13.3 & \\
\hline $\begin{array}{l}\text { Age less than } 25 \text { years } \\
(n=72)\end{array}$ & 50 & 69.4 & 14 & 19.4 & 8 & 11.11 & 0.02 \\
\hline $\begin{array}{l}\text { Age between } 25-30 \text { years } \\
(n=82)\end{array}$ & 53 & 64.6 & 20 & 24.3 & 9 & 10.9 & \\
\hline $\begin{array}{l}\text { Age more than } 30 \text { years } \\
(n=31)\end{array}$ & 11 & 35.4 & 12 & 38.7 & 8 & 25.8 & \\
\hline $\begin{array}{l}\text { Experience less than } \\
5 \text { years }(n=72)\end{array}$ & 49 & 68.0 & 13 & 18.0 & 10 & 13.8 & 0.01 \\
\hline $\begin{array}{l}\text { Experience } 5 \text { - } 10 \text { years } \\
(\mathrm{n}=89)\end{array}$ & 51 & 57.3 & 26 & 29.2 & 12 & 13.4 & \\
\hline $\begin{array}{l}\text { Experience more than } \\
5 \text { years }(n=23)\end{array}$ & 5 & 21.7 & 10 & 43.4 & 8 & 34.7 & \\
\hline
\end{tabular}

Table 4: Comparison of pre training and post training test responses according to training schedule hospital staff have undergone

\begin{tabular}{lcccc}
\hline Training Schedule & $\begin{array}{c}\text { Pertaining } \\
\text { Response } \\
\mathbf{X} \pm \text { s.s }\end{array}$ & $\begin{array}{c}\text { Post training } \\
\text { Response } \\
\mathbf{X} \pm \mathbf{s . s}\end{array}$ & \multicolumn{2}{c}{ Statistical Significance } \\
\cline { 3 - 5 } & $30.84 \pm 2.86$ & $36.18 \pm 5.32$ & -6.58 & $\mathbf{p}$ \\
\hline $\begin{array}{l}\text { Staff never underwent } \\
\text { any training schedule }\end{array}$ & $31.72 \pm 4.27$ & $37.12 \pm 4.14$ & -10.96 & 0.000 \\
$\begin{array}{l}\text { Staff underwent training } \\
\text { schedule once }\end{array}$ & $33.15 \pm 3.46$ & $39.05 \pm 2.86$ & -12.86 & 0.000 \\
$\begin{array}{l}\text { Staff underwent training } \\
\text { schedule more than once }\end{array}$ & & & & \\
\hline$p<0.05$ & & &
\end{tabular}




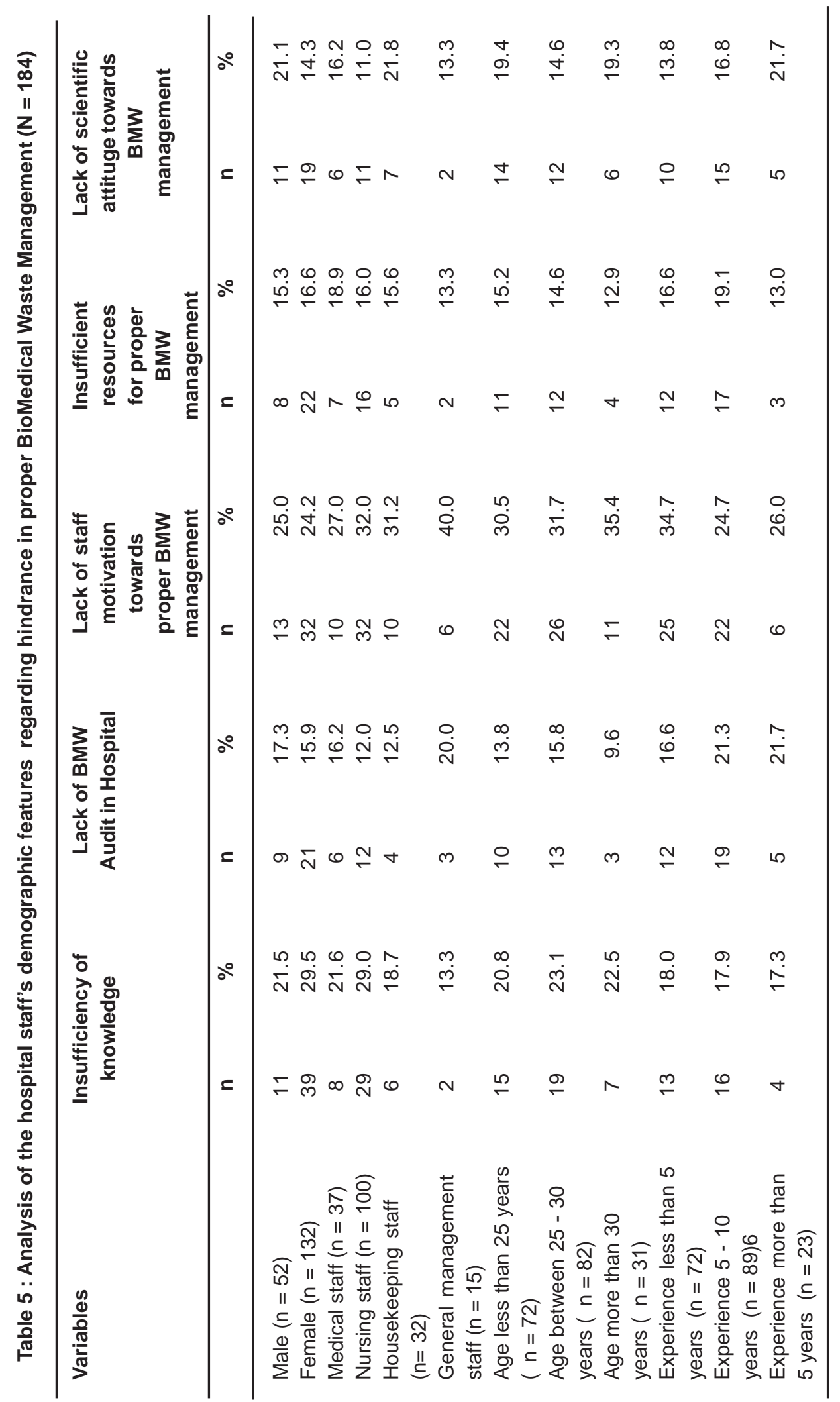


statistically higher in female staff $54.5 \%$ (72) then male $44.2 \%(23)(p<0.005)$

It was also revealed that $3.7 \%$ of nursing staff, $8.2 \%$ of medical staff and $7.9 \%$ of housekeeping staff and $4.8 \%$ general staff had not received training whatsoever on the subject of waste management in hospital. The staff who have receive at least one training constitute majority of the participants. Except general management staff participants maximum of the participants have receive the training on the biomedical waste management in their previous organization. In the study it was also observed that those participants who have not received any previous training on the subject in pre training and post training test scored lower than those who have received previous training on the subject of biomedical waste management.

According to the collected data on problems regarding biomedical waste management $17.7 \%$ responded that sufficient attention towards its scientific management process was not paid while $16.6 \%$ said auditing was lacking ,24.6\% referred to lack of intensity towards work and $25.5 \%$ claimed the insufficiency of work knowledge on waste management.

All participants to varied degree appreciated that solution to the problems of effective biomedical waste management is necessity of the structured training and audit because they felt that the greater problem encountered by hospital staff on the biomedical management was lack of waste audit in the institution. the results of the study pointed out that hospital staff of all department and demographics cited the primary problem on the subject as insufficiency of emphasis.

\section{DISCUSSION}

The waste generated in the hospital as a result of either after diagnostic or curative patient care poses potential health risk to care givers, patients, population and environment. If this waste is not segregated, collected, stored, transported, treated and disposed off by use of appropriate methods they will emerge as severe public health and environmental problems.

The onus of biomedical waste management lies with the hospital occupier. the information levels and awareness of hospital staff on the subject of biomedical waste management is very important in the process of waste management.

On review of literature it was revealed that majority of the staff $(69.9 \%)$ had received appropriate training on the subject of biomedical waste management. according to another study the level of information among hospital staff on waste management $62.1 \%$ of medical doctors ,54.5\% nursing staff while $47.6 \%$ laboratory technician staff were well informed about the subject on biomedical waste management ${ }^{6}$. Similarly another study pointed out that medical staff, nurses, and laboratory technicians are well informed about theprocess of managing biomedical waste appropriately ${ }^{8}$

The study conducted by Suvarna and Ramesh in 2012 showed that medical officers and nursing staff had higher level of information then other hospital staff about biomedical waste management process $^{9}$

Laxmi and Kumar conducted an analysis among the healthcare workers on the awareness of biomedical waste management. In the study the finding is that an information and awareness deficiency among the hospital employees as tot the legislation associate with biomedical waste management. IN this study performed on qualified hospital employees also indicates that a knowledge and awareness deficiency exist among the qualified hospital personnel about the legislation on biomedical waste management ${ }^{10}$. The result of present study too is consistent with the conclusion drawn in various other research papers dealing in the information level regarding biomedical waste management among hospital employees ${ }^{1,9,10}$.

The present study also revealed that hospital employees had better scores in knowledge test score which was done after training session on the subject. As evident the awareness level got 
improved after the training which clearly indicate the effectiveness of structured training to study participants. as the number of hospitals are increasing the quantum of waste will also increase proportionately. In order to eliminate the potential danger posed by growing quantum of waste to human and environmental health, it is mandatory for hospital employees be armored with "hospital or biomedical waste management plan" and be given regular training on every type so waste produced during the diagnostic and curative patient care in the hospital and healthcare facilities.

The importance of periodic repeated training has become evident in the present study that the knowledge and awareness level of hospital staff was found to be more in the pre training and post training test for the staff member with each training session more than others. This finding give the support to thought process of importance of periodic training programme on biomedical waste management so as to fill the deficiency levels in information about subject among the hospital employees. it is therefore propose that in order to have effective biomedical waste management prog $4 \mathrm{rmme}$ in the hospital it need to draw an effective waste management plan and have that plan continually implemented by periodic training of staff members.

Compliance to the policies and procedures related to biomedical waste management is directly related to the knowledge and awareness about process and this attitude and knowledge is updated with the help of periodic training in the subject. It is therefore evident that training is as essential part of the hospital employee's daily activity so as to have proper and scientific management of the biomedical waste generated in the hospital. In the present study it emerged that to organize and implement a standardised and structured training programme for all staff member of the hospital will play a very important role in solution of the waste management issue.

\section{REFERENCES}

1. Kishore J, Ingle G K,Biomedical Waste Management in India, IstEdition, Century Publication (New Delhi), 2004.

2. Glan Mc R, Garwal R, Clinical Waste in Developing Countries. An Analysis with case study of India and a critique of Basle TWG guidelines (1999).

3. Khan M S, Sana's Guidelines for Hospital Infection control, IstEdition, Jaypee Brtothers (New Delhi), (2004).

4. Kishore J, Joshi T K, Biomedical Waste Management, Employment News, 19-25 (2000).

5. Basarkar s, hospital waste management: A Guide for Self Assessment and Review, $\left.\right|^{\text {st }}$ Edition, Jaypee Brothers, (New Delhi), (2008).

6. Jhanvi G, Raju P V R, Awareness and training need of biomedical wase management among undergraduate students, AndhraPradesh, Quarterly Journal of the Indian Public health association,volxxxxx No1, January-March ,
53-54 (2006).

7. Vishal B, Swarn L, Mahesh M, Arvind A, Sanjay A, Uma S: Knowledge Assessment of Hospital Staff Regarding Biomedical Waste Management in A Tertiary Care Hospital. Nat J Community Med, 3(2):197200 (2012).

8. Mathur V, Dwivedi S, Hassan MA, Misra RP: Knowledge, attitude, and practices about biomedical waste management among healthcare personnel: A cross-sectional study. Indian J Community Med, 36: 143-145 (2011).

9. Suwarna M, Ramesh G: Study about awareness and practices about healthcare wastes management among hospital staff in a medical college hospital, Bangalore. Int J Basic Med Sci, 3(1): 7-11 (2012).

10. Lakshmi BS, Kumar P: Awareness about biomedical waste management among healthcare personnel of some important medical centers in Agra. Int J Eng Res Tech, 1(7) :1-5 (2012). 